\title{
THE CONCEPTS AND THE ESSENCE OF INTERPRETATION OF LAW
}

\author{
Oleh Bilous ${ }^{1}$, Pavlo Liutikov²
}

\begin{abstract}
The purpose of the paper is to define the concept and essence of the interpretation of the rules of law based on the generalized analysis of scientific, journalistic, and regulatory sources. Results. It is established that the interpretation of the rules of law is an intellectual and volitional activity of an interpreter, which is carried out under the principles and by means of interpretations and aimed at clarifying and/or specifying the content of the rules of law to understand and apply them in practice correctly and uniformly. Value/originality. It may be enshrined in special acts of interpretation, scientific and practical commentary on legislation, doctrinal sources and other external forms of interpretation.
\end{abstract}

Key words: interpretation, law, rule of law, essence, object, purpose.

JEL Classification: K10, K15, K38

\section{Introduction}

The complexity of legal interpretation and the ambiguity of its results always arise a genuine interest of both legal scholars who study general theoretical issues and scholars who deal with the problems of branches of legal sciences. Essentially, from the beginning of the $40 s-60$ s of the past century, i.e. from the moment of the final establishment of the so-called theory of legal interpretation in the domestic legal doctrine, till the present, representatives of the scientific law society have been pursuing answers to the following questions: "What is interpretation of law? What are its real resource and potential? What is an object? Finally, what is a subject of this complex intellectual-volitional process?

Taking into account that social relations are dynamic and fast-changing, law controlling them is also subject to transformation. One can objectively assume the abovementioned scientific questions concerning the interpretation of legal rules will never become obsolete and lose social importance. Moreover, it is essential to consider that law, changing its regulatory options, requires a revision and renewal of approaches to its interpretation.

It seems these factors have also influenced the fact that, even at a conservative estimate, domestic and foreign scholars have written more than a hundred theses and monographs devoted to various issues of interpretation of law, and the number of scientific articles cannot be counted at all. It stands to reason that such a diversity of scientific material indicates the ambiguousness in

\footnotetext{
Corresponding author:

${ }^{1}$ Supreme Court, Ukraine.

E-mail: suddya09@gmail.com

${ }^{2}$ University of Customs and Finance, Ukraine.

E-mail: lyutikovp@gmail.com
}

settling challenging issues for science. Consequently, this complexity has brought about one can make bold to suggest on several independent and diametrically opposing views on the interpretation of law and its rules.

\section{Generalized analysis of theory of interpretation in the Soviet period of legal doctrine development}

Despite the statement that theory of statutory interpretation was developed in the mid-20th century, the authors consider it necessary to refer to the scholarly works of those scientists who are treated as its founders and whose scientific heritage is still relevant. Thus, E. N. Trubetckoi asserted it was not enough to be sure of the existence of a legal rule for the application of law, it was necessary to clarify the content of the rule to be applied. According to the prominent scientist, in order to establish the precise content of the rule, the text which notifies us of its availability is subject to grammatical analysis. If this involves the laws, their text can be subject to analysis. E. N. Trubetckoi believed that interpretation of law was not limited to grammatical analysis. The interpretation focuses on clarifying the intrinsic meaning of legal provisions. That sort of interpretation, which stays within the letter of the law, is highly dangerous and can cause numerous abuses. Relying on the above, he said the clarification of the spirit of the law, intentions and objectives the legislator implied was a real purpose and primary task of any interpretation (Trubetckoi, 1998). 
Such researchers as Ye. V. Vaskovskyi, A. A. Rozhdestvenskii, M. S. Tagantcev, M. D. Shargorodskii et al. generally supported him or expressed similar views. In the Soviet period of the development of legal doctrine, most of the ideas of the mentioned authors were rejected, scientific concepts were called in doubt in terms of their expediency and correspondence with the interests of the working class, and the very scholars were called bourgeois.

Iu. G. Tkachenko was one of the pioneers who updated the issues of interpretation of legal rules at the level of thesis research in the Soviet period. As the vast majority of studies of the Soviet period, Iu. G. Tkachenko's thesis substantiated the social relevance of the specific topic by the fact that "interpretation of legal rules in the USSR is essential to enhance the rule of law particularly significant for our state in the period of completion of the building of socialism and the gradual transition to communism. The necessity of addressing matters related to the interpretation of legal rules is conditioned both by the importance of the very interpretation and a lack in the Soviet legal literature of innovative research dealing with the interpretation as one of means for establishing and enhancing legality in the Soviet state" (Tkachenko, 1950). Specifically, Iu. G. Tkachenko, in the context of intolerance to dissent typical for that epoch, believed that despite the fact that interpretation should consolidate the application of the Soviet laws, this process plays an entirely different role in capitalist countries - the bourgeoisie breaks the laws previously established by it through using the interpretation. The author individually wrote about it and reasoned his standpoint in full" (Tkachenko, 1950). For the most part, criticism is focused on the whole common law in which, as known, the position of precedent is indisputable among sources of law. The Soviet scientist regarded the mentioned practice and natural law theory as maleficent to the interpretation in the eye of the law. This even allowed Iu. G. Tkachenko to arrive at the idea that "... in the bourgeois states in the age of imperialism, the rule of law was destroyed, the arbitrariness of both judicial and administrative bodies was established, and the rejection of the rule of law was particularly evident in England and the United States" (Tkachenko, 1950). Nonsense of the above statements, or rather the origin of that sort of idea, is easy to explain since the influence of official ideology on science, including legal one, was extremely strong at the time (Bilous, 2020).

Turning to the approach of Iu. G. Tkachenko, especially to the issue of the interpretation of legal rules, the scientist believed the Soviet interpretation is instrumental in establishing a common understanding of the law, its uniform application across the Soviet Union. In the scientist's opinion, interpretation is one of the most important tools for conducting and enhancing the rule of law to establish a common understanding and application of the laws. For this reason, in his thesis, Iu. G. Tkachenko concluded that interpretation could not and should not amend legal rules. "It solely details and clarifies the available provisions of the law. Interpretation of legal rules cannot be identified with lawmaking. Lawmaking involves creating new legal provisions, new rules. Interpretation of these rules cannot and should not create a new law. The Soviet interpretation does not focus on changing the laws, as in capitalist countries, but enhancing the laws through their clarification and specification" (Tkachenko, 1950).

Fully sharing the scientist's opinion that interpretation does not create a new legal rule, the authors note there is no point to criticize the common law for its peculiarity, including interpretation as one of the lawmaking stages, which results in a specific legal precedent - a judicial decision. Essentially, there should not be a discussion under the framework of determining the legal nature of an outcome of the interpretative process. It appears to the authors that Iu. G. Tkachenko understood it as well, but given the impact of the Soviet ideological steamroller, he was forced to catch an error in "the bourgeois law" and highlight its highly adversarial and injurious nature to society.

Turning back to the matters of the development of scientific theories of interpretation in the Soviet period, it is worth mentioning the contributions of A. S. Pigolkin, who devoted a large number of his works to the issue under consideration. $\mathrm{He}$, as well as Iu. G. Tkachenko, was very critical of the "bourgeois" understanding of interpretation and stressed that "... against the backdrop of socialist reality, interpretation of legislative instruments is one of the ways of implementing the policy of the Communist Party of the USSR (Pigolkin, 1962). Moreover, his ideas of the very essence of interpretation were the most valuable for science. It was A. S. Pigolkin who insisted that clarification and interpretation cannot be a part of the same process. He found them acting as inconsistent and independent phenomena. Referring to N. G. Aleksandrov, A. S. Pigolkin emphasized that interpretation is a generic concept, comprising two individual and different generic concepts which, firstly, should be understood as the internal mental process taking place in the consciousness of a person who applies a legal rule, the clarification of the content of the legal rule and its explanation; secondly, interpretation is externally expressed clarification of the provisions of the legal rule, which is objectified both in the form of an official act of the state authority, recommendations, and advice provided by nongovernmental organizations or individuals having no binding effect (Pigolkin, 1962). Drawing a clear line between clarification and explanation, the Soviet scientist wrote that interpretation, as clarification 
of a legal rule, is a necessary preparatory stage for an adequate solution of a particular issue, required prerequisite for the operation of legal rules in public life, while interpretation-explanation acts as an independent, special activity of certain bodies and individuals (Pigolkin, 1962; Bilous, 2020).

Consequently, A. S. Pigolkin asserted interpretation aims to establish and clear up the will of the dominant class (and the will of the whole nation in the period of active building of communism) expressed in the law or other statutory act. This determines the commonality of the following issues for all aspects of interpretation: a class nature of interpretation, the extension of general philosophical questions of cognition to the interpretation matters, the connection of interpretation with the general tasks of enhancing socialist legitimacy (Pigolkin, 1962). Being guided by the above ideas, the scientist argued that interpretation of regulations in the Soviet state is the activity of government bodies, nongovernmental organizations and individual citizens oriented to identify the will of the Soviet people expressed in the regulations and cover the authentic content of this will (Pigolkin, 1962).

Indeed, P. O. Nedbailo did not share A. S. Pigolkin's approach. P. E. Nedbailo categorically rejected the idea that interpretation is limited to clarifying a legal rule. In this regard, being in agreement with $\mathrm{O}$. S. Ioffe and M. D. Shargorodskii, he wrote "the attempts to separate the explanation of the essence and content of legal rules from the interpretation of a legal act, as the clarification of the content of legal rules, have purely dogmatic nature. The concept of clarification of the legal rules, as a process of learning them for oneself, has no legal significance, and thus, it is useless as a legal term (Nedbailo, 1960). Somewhat, the authors share the mentioned idea considering that clarification of a legal rule is a preliminary stage for its explanation. Clarification of the content of the legal rule makes sense per se, but it is devoid of legal significance without explanation. Therefore, in the context of the so-called interpretation-clarification, it is expedient to refer to an unofficial or so-termed "common" or "routine" interpretation conducted by ordinary citizens or other subjects exclusively for clarifying the content of the legal rule and recognizing its essence to specify the use of their rights and performance of duties.

As an intermediate conclusion about the Soviet period of the development of legal science, for justice, it is worth mentioning that by giving up on the ideas of representatives of the pre-revolutionary legal science, the Soviet legal doctrine could provide its visions of the interpretation of law and its rules as quite weighty arguments. At the same time, an aggressive rhetoric concerning the approaches of foreign scholars and those domestic researchers, who favored a concept of interpretation of law similar to Western scholars, was not valid and objective.

\section{Analysis of modern approaches to the interpretation of legal rules}

S. V. Pryima justifies close relationship between the interpretation of legal rules and some systems of philosophy, including hermeneutics and phenomenology. In addition, the scientist outlines the main features of interpretation of law: 1) it is a kind of legal activities; 2) it has (intellectual, mental, creative) nature; 3 ) it has a purposive character; 4 ) it has a clarifying (concretization) nature conditioned by standardized nature of law; 5) it has an indirect character; 6) it is performed by different subjects, the particularities of which determine a type of interpretation; 7) it is based on the relevant principles. Following the specified features, S.V. Pryima defines the interpretation of law as a type of legal activities which are cognitive, rely on particular principles and are conducted by relevant subjects for detecting and specifying the content of legal rules and, when necessary, include its explanation for other subjects (Pryima, 2011).

In O. E. Leist's opinion, the interpretation of a legal rule is the clarification and explanation of its real content which is subject to be realized under specific conditions of its action (Leist, 2002; Bilous, 2020). Zh. M. Melnyk-Tomenko expresses a quite similar standpoint. Studying the principles of interpretation of the general principles of administrative proceedings regarding the practice of the European Court of Human Rights, she notes the interpretative process consists of two parts. According to the scientist, at the first stage, the rule should be understood, i.e., an executor of law or a subject of interpretation should come to grips with the rule. At the next stage, the interpreter clarifies the legal rule for other subjects. At the same time, the scientist notes that this mental process does not necessarily result in the approval of an individual interpretative act, but may find expression in the text of scientific-practical commentary on a statutory act, scientific article, speech of a lawyer or a representative in court etc. (Melnyk-Tomenko, 2020; Bilous, 2020).

O. V. Kaplina also writes about the staging of interpretation, but her standpoint somewhat differs from the above one. Thus, in the scientist's opinion, clarification is not always an obligatory stage of interpretation of a legal rule. O. V. Kaplina marks that every stage of the interpretation has its inherent features, specific characteristics, an aim, content, a form and implementation methods. Clarification is the first element of interpretation and ensures the understanding of a legal rule during the law-making, application of legal rules, systematization of legislative acts. As the scientist rightly notes, the solution of the issue on the stages of interpretation and their interrelations depends on the fact what type of interpretation is maintained, the parties involved and 
a purpose of legal interpretation. In O. V. Kaplina's strong opinion, although clarification of the essence of a legal rule under interpretation is closely interrelated with explanation, they are independent processes. Clarification is essential but not obligatory element of the interpretative process. However, it is an essential part of law-application interpretation. Such an approach to the understanding of interpretation, which combines clarification and explanation, allows regarding the interpretation of a legal rule as a method of cognition, on the one hand, and the interpretation as a type of legal activities, on the other hand (Kaplina, 2008).

Yu. L. Vlasov defines the interpretation of legal rules as an intellectual-volitional activity of objective and subjective nature along with the clarification and explanation of the legislator's will embodied in a legal rule and an outcome of this activity. Moreover, the researcher, as well as O. V. Kaplina, specifies that a balance between clarification and explanation should be established according to the intended purpose of the legal rule. When interpreting the legal rule, clarification acts as an independent cognitive process for understanding of its nature. When it is established a purpose of elucidating the essence of a legal rule, clarification and interpretation compose a single process focused on explaining the rule's provisions to the third parties (Vlasov, 2011; Bilous, 2020).

Instead, O. I. Kostenko does not divide two mentioned intellectual and volitional processes as it proceeds from the scholar's definition of "the interpretation of administrative law acts". It is rendered as the mental intellectual-volitional activity of a relevant subject of interpretation, which is characterized by specific methods and ways and enshrined in special acts of interpretation, aimed at clarifying and explaining the essence and scope of administrative rules, a particular administrative law act or its respective regulatory prescription for their correct and similar understanding and practical application (Kostenko, 2011).

In view of the above, V. V. Honcharov marks that the term "interpretation of legal rules" denotes two related but not identical phenomena. The former is driven by the clarity of a rule for a recipient, i. e. when there is no doubt about its content, and thus, there is no need to reformulate the rule more clearly. That sort of phenomenon can be represented by the term "interpretation-comprehension". Indeed, the latter is associated with the recipient's incomprehensibility of text of the rule that causes the need to convey its some lexemes clearer. Such a phenomenon can be rendered by the term "interpretation-explanation" (Honcharov, 2013). In the authors' opinion, activities related to the interpretation of legal rules are performed independent of a degree of their clarity for the recipient, as it involves the definition of such content not in the abstract, but in terms of a specific subject (legal relationship). At the same time, "content" of the rule is an object of the interpretation in either case or "a form of its consolidation" within this study for establishing its "content". It would be a mistake to regard the content of the rule as an object of interpretation, since the interpretation aims to establish its real content (Bilous, 2019).

Iu. N. Todyka wrote about the interpretation differently: "the very term of "interpretation of law" may be understood: firstly, as a specific cognitive process oriented to determine the meaning (content) of the legal rules... secondly, as an outcome of the cognitive process which is conveyed in a range of statements (grammatical sentences) covering and rendering the content of the rules being interpreted (Todyka, 2000).

Therefore, A. G. Manukian admits that the results of interpretation can exceed the limits of law enforcement. The researcher believes one can refer to the creation of new rules under the framework of "corrective kind of interpretation”. A. G. Manukian says "an interpreter may be beyond the scope of the literal meaning of words and expressions of the legislative rule under the extensive interpretation as well, however, it is found out the essence of a rule the legislator intended it to have while adopting one - a new rule is not created. Under corrective interpretation, there is a deviation from the original intention of the legislator - rather other social relations are subjected to the regulation than those which the legislator meant when adopting the rule".

In the same context, A. G. Manukian turns to the socalled modernized kind of corrective interpretation of legal rules which is applied: either taking into account the essential, but not considered by the legislator, specifics of social relations in one or another segment of social reality, or by changing the objective meaning of this reality. However, the scholar emphasizes an executor of law changes the literal meaning of the legal rule at his or her discretion. Admitting that the purpose of statutory interpretation is to identify the content of a legal rule without going beyond the principle of separation of powers, A. G. Manukian stresses such a condition does not mean that modernized corrective interpretation is always wrongful, and the executor of law does not have the right to form other legal relations than those which proceed from the interpreted legislative prescription (Manukian, 2006).

Therewith, the abovementioned Yu. L. Vlasov says that under the framework of legal activities, the interpretation of legal rules is encountered not only amidst law enforcement but also lawmaking, enforcement, systematization, legal education and promotion of law. Moreover, the scholar specifies that in the context of legal regulation, the interpretation should be considered narrower through separating its tasks and functions from other types of legal activity such as legal specification, filling law gaps, adjustment of the rules to new living conditions etc. (Vlasov, 2001; Bilous, 2020). 
M. I. Koziubra also admits a fact interpretation is not limited to clarification and explanation. The scientist makes some adjustments concerning the mentioned conclusion. Thus, in the scientist's opinion, lawmaking is not a function (i.e. one of the main activities) of law interpretation agencies, including courts. Giving them that sort of authority would contradict the principle of separation of powers the opponents of judicial lawmaking reasonably paid attention to. Consequently, it is pointless to apply the English "judge-made law" by rote to the domestic legal system and the continental legal system. In addition, M. I. Koziubra notes it would be more facilitated to regard law enforcement, primarily judicial practice and even more practical activity of the constitutional review bodies - constitutional courts, as something independent of the lawmaking process. The availability of lawmaking elements in law interpretation activity is not an anomaly - as the national literature often qualifies - but an objective need. Although it has its limits, it shall not be deleted in its entirety from the activities of the Constitutional Court and general jurisdiction courts as it is inherent in the very nature of their activities (Koziubra, 2014).

M. I. Koziubra assures that to deny the obvious facts of judicial interpretation's violation of the limits of clarification and explanation of the will of the constitution-maker or legislator, scope of the relevant constitutional or legislative provisions, which are conveyed by meaning that often differs from the essence which the constitution-maker or legislator, entails keeping the positions of extreme formalism and dogmatism incompatible with modern ideas about law and man's belonging to it. Therefore, the prominent legal theorist specifies that the foregoing does not mean that judicial interpretation - a lawmaking or judicial "completion" and "development" of law - has no limits and is determined solely by judicial discretion (Koziubra, 2014).

Having analyzed the above approaches to interpretation of law, the authors do not share the opinions of those scholars who either insist that interpretation is a law-making process in the context of our legal reality or allow "exceptions to the rule of traditional understanding of interpretation" and try to explain the logic of the decisions taken by jurisdictional entities, which are not only law enforcement acts in specific cases but also acts that were subsequently applied by other subjects of law which took the motivating and operative part of the court decision as a basis.

\section{Conclusions}

Taking into consideration all the abovementioned opinions of both domestic and foreign scholars, the authors mark that, as legal literature rightly notes, one can draw the following conclusion relying on a large variety of approaches to the definition of the concept "interpretation of law": despite the discordance of scientific opinions, the majority of representatives of domestic and foreign scientific schools agree that interpretation can be understood in two senses - as a process or a result (Zvieriev, 2015). In addition, this procedure involves two other processes - clarification and explanation - which, according to some scholars, can exist as complementary components of a single process and, in the opinion of others - are independent, not always interconnected (interdependent) intellectual and volitional processes - "interpretation-clarification" and "interpretation-explanation".

The authors state interpretation is not an individual stage or type of rulemaking which results in the creation of a new rule oflaw. It is worth highlighting that among the above arguments, the authors' vision of interpretation is based on the fact the word "interpretation" (Latin "interpretatio") means in common sense nothing more than "to determine the content, to explain, to clarify the essence of something; to give some explanation" (Busel, 2001). In other words, the very semantics of the words of "interpretation" and "elucidation" does not provide for other intellectual and volitional processes except clarification and explanation, and attempts to expand the meaning of these words through specification a new rule is created due to these mental processes contradict their well-known meaning (Bilous, 2020).

The research highlights that so-called judicial interpretation, M. I. Koziubra writes about in the context of the specified discussion, can go beyond the lawenforcement process and get the features of lawmaking. However, the authors believe the above can take place in cases of law interpretation activity of the Constitutional Court of Ukraine and European Court of Human Rights that is prescribed by the current legislation of Ukraine whereby, for instance, the courts apply the ECHR practice as a source of law when considering cases.

At the same time, the authors agree that a specific result of the interpretation set out in a relevant court decision (primarily, of higher courts) may be a ground for reviewing the case law on a particular category of cases. There is no gainsaying that in such cases, the rule of law didn't change but get, so to speak, its new, more correct understanding and use patterns. The authors also recognize that the results of law enforcement or doctrinal interpretation may impact lawmaking, if an error or incompleteness of legal regulation of social relations was found due to such interpretive processes of a law or legal rules and the legislator subsequently made appropriate changes to the law (Bilous, 2020).

In the authors' analysis, a just opinion is one under which the "stages" and complexity of the interpretative process depend on the purposes of interpretation and its varieties respectively. Thus, if it refers to so-called unofficial interpretation, this process involves clarifying the rules of law and does not provide for the legal consequences of that sort of interpretation. If it refers to 
the official interpretation, it is evident the interpretative process comprises two interrelated stages - clarification and explanation.

Consequently, interpretation of legal rules is an intellectual and volitional activity of an interpreter, which is conducted under the principles and means of interpretation, aimed at clarifying and/or specifying the content of the legal rule to understand and apply them in practice correctly and uniformly. It may be enshrined in special acts of interpretation, scientific practical commentary on legislation, doctrinal sources and other external forms of interpretation (Bilous, 2020).

\section{References:}

Bilous, O. V. (2019). Poniattia obiekta tlumachennia yak elementa pravozastosovnoi diialnosti [The concept of an object of interpretation as an element of law-enforcement activity]. Pidpryiemnytstvo, hospodarstvo i pravo, vol. 3, pp. $132-136$.

Bilous, O. V. (2020). Liudynotsentrychni ta aksiolohichni aspekty tlumachennia poniat ta katehorii administratyvnoho sudochynstva: monohrafiia [Human-centric and axiological aspects of the interpretation of concepts and categories of administrative proceedings: a monograph]. Odesa: Publishing House Helvetica. (in Ukrainian)

Bilous, O. V. (2020). Poniattia ta katehorii administratyvnoho sudochynstva: liudynotsentrychni ta aksiolohichni aspekty tlumachennia [Concept and categories of administrative proceedings human-centric and axiological aspects of interpretation] (PhD Thesis), Dnipro. (in Ukrainian)

Bilous, O. V. (2020). Tlumachennia norm prava: poniattia ta sutnist [Interpretation of legal rules: concept and essence]. Jurnalul juridic national: teorie şi practică, vol. 3, pp. 46-53.

Busel, V. T. (ed.) (2001). Velykyi tlumachnyi slovnyk suchasnoi ukrainskoi movy [Great explanatory dictionary of the modern Ukrainian language] Kyiv: Irpin: VTF "Perun”. (in Ukrainian)

Honcharov, V. V. (2013). Dynamichne tlumachennia yurydychnykh norm [Dynamic interpretation of legal rules] Pratsi Lvivskoi laboratorii prav liudyny i hromadianyna NDI derzhavnoho budivnytstva ta mistsevoho samovriaduvannia NAPrNU. Seriia I. Doslidzhennia ta referaty, vol. 27 [Papers of Lviv Laboratory for Human and Civil Rights of the RI of State Building and Local Self-Government of the NALSU. Series I: Research and abstracts]. Lviv: SPOLOM. (in Ukrainian)

Kaplina, O. V. (2008). Pravozastosovne tlumachennia norm kryminalno-protsesualnoho prava: monohrafiia [Law-enforcement activity of the rules of criminal procedural law: a monograph]. Kharkiv: Pravo. (in Ukrainian)

Kostenko, O. I. (2011). Tlumachennia aktiv administratyvnoho zakonodavstva [Interpretation of administrative law acts] (PhD Thesis), Zaporizhzhia. (in Ukrainian)

Koziubra, M. I. (2014). Yurydychne tlumachennia: problemy metodolohii [Legal interpretation: methodological problems]. Naukovi zapysky NaUKMA. Yurydychni nauky, vol. 155, pp. 3-8.

Leist, O. E. (2002). Sushchnost prava. Problemy teorii i filosofii prava [The essence of law. Problems of theory and philosophy of law]. Moscow: IKD Zertsalo-M. (in Russian)

Manukian, A. G. (2006). Tolkovanie norm prava: vidy, sistema, predely deistviia [Interpretation of legal rules: types, system, action limits] (PhD Thesis), St. Petersburg. (in Russian)

Melnyk-Tomenko, Zh. M. (2020). Zastosuvannia praktyky Yevropeiskoho sudu z prav liudyny pry tlumachenni zahalnykh pryntsypiv administratyvnoho sudochynstva [Application of the practice of the European Court of Human Rights when interpreting the general principles of administrative proceedings] (PhD Thesis), Dnipro. (in Ukrainian)

Nedbailo, P. E. (1960). Primenenie sovetskikh pravovykh norm [Application of the Soviet legal rules]. Moscow: Iuridicheskaia literatura. (in Russian)

Pigolkin, A. S. (1962). Tolkovanie normativnykh aktov v SSSR [Interpretation of statutory acts in the USSR]. Moscow: Iuridicheskaia literatura. (in Russian)

Pryima, S. V. (2011). Pryntsypy tlumachennia norm prava [Principles of the interpretation of legal rules] (PhD Thesis), Kharkiv. (in Ukrainian)

Tkachenko, Iu. G. (1950). Tolkovanie iuridicheskikh norm v SSSR [Interpretation of legal rules in the USSR] (PhD Thesis), Moscow. (in Russian)

Todyka, Iu. N. (2000). Konstitutciia Ukrainy: problemy teorii i praktiki: monografiia [The Constitution of Ukraine: theoretical and practical issues]. Kharkov: Fakt. (in Russian)

Trubetckoi, E. N. (1998). Entciklopediia prava [Law encyclopedia]. Saint-Petersburg: Iuridicheskii institut. (in Russian)

Vlasov, Yu. L. (2000). Problemy tlumachennia norm prava [Challenges of the interpretation of legal rules] (PhD Thesis), Kyiv. (in Ukrainian)

Vlasov, Yu. L. (2001). Problemy tlumachennia norm prava: monohrafiia [Problems of the interpretation of legal rules: a monograph]. Kyiv: In-t derzhavy i prava im. V. M. Koretskoho NAN Ukrainy. (in Ukrainian)

Zvieriev, Ye. O. (2015). Tlumachennia mizhnarodnykh dohovoriv natsionalnymy sudamy: yevropeiskyi dosvid ta ukrainska praktyka [Interpretation of international agreements by the national courts] (PhD Thesis), Kyiv. (in Ukrainian) 